\title{
The Kantian (Non)-Conceptualism Debate
}

\author{
Colin McLear \\ University of Nebraska-Lincoln \\ mclear@unl.edu \\ July 21,2014
}

\begin{abstract}
One of the central debates in contemporary Kant scholarship concerns whether Kant endorses a "conceptualist" account of the nature of sensory experience. Understanding the debate is crucial for getting a full grasp of Kant's theory of mind, cognition, perception, and epistemology. This paper situates the debate in the context of Kant's broader theory of cognition and surveys some of the major arguments for conceptualist and non-conceptualist interpretations of his critical philosophy.
\end{abstract}

\section{Introduction}

$\mathrm{O}$ NE OF THE CENTRAL TOPICS OF DEBATE in contemporary Kant scholarship has been whether Kant endorses a position concerning the nature of sensory experience called "conceptualism." As a first approximation, conceptualism about experience is the claim that the capacity for conscious sensory experience of the objective world depends, at least in part, on the repertoire of concepts possessed by the experiencing subject, insofar as they are exercised in acts of synthesis by the cognitive faculty which Kant terms the "understanding" [Verstand]. Exactly how we should understand this dependence relation, as well as the notion of experience that it presupposes, is something we will discuss in much further detail below. The historical question as to whether Kant endorsed conceptualism has also been linked to the philosophical question as to the commitments of the conceptualist position and whether it is, in the end, a tenable one.

For the purposes of this article I shall focus primarily on the historical question, and thus I will largely ignore issues in the philosophy of mind and perception literature that have arisen independently of the scholarly debate concerning Kant. ${ }^{1}$

The argument of this paper proceeds as follows. §2 briefly sketches the fundamental elements of Kant's theory of cognition. $\$ 3$ articulates several major considerations which help to define the non-conceptualist interpretation of Kant. In $\S 4$ I elaborate the conceptualist interpretation of Kant. I present and to some extent revise what I take to be the core interpretive commitments of the conceptualist position. $\$ 5$ discusses several major objections to conceptualism and non-conceptualism, as well as a central issue of contemporary interest-viz. the so-called "Myth of the Given" and its connection to the conceptualism debate. I then summarize the argument of the paper.

1 For a useful overview of the contemporary literature see Gunther (2003); Siegel (2010); Van Cleve (2012). 


\section{A Sketch of Kant's Theory of Cognition}

Kant's conception of our mental economy is basically tripartite, consisting of sensations [Empfindungen], intuitions [Anschauungen] and concepts [Begriffe]. ${ }^{2}$ These are all varieties of what Kant calls "representation" [Vorstellung]. ${ }^{3}$

In what is generally called the "stepladder" [Stufenleiter] passage from the Transcendental Dialectic of the first Critique, one of the few places in the Kantian corpus where he explicitly discusses the meanings of and relations between his technical terms, Kant defines and classifies varieties of representation.

The category is representation (representatio) in general. Under it stand representations with consciousness (perceptio). A perception [Wahrnehmung], that relates solely to a subject as a modification of its state, is sensation (sensatio). An objective perception is cognition (cognitio). This is either intuition or concept (intuitus vel conceptus). The first relates immediately to the object and is singular; the second is mediate, conveyed by a mark, which can be common to many things (A320/B376-7). ${ }^{4}$

As Kant's discussion here indicates, the category of representation contains sensation, intuition, and concept. The faculty that provides sensory representations is called "sensibility" [Sinnlichkeit]. Sensibility generates representations based on being affected either by entities distinct from the subject or by the subject herself. This is in contrast to the faculty of "understanding" [Verstand] which generates representations "spontaneously" - i.e. without advertance to affection.

2 There are other signficant representational kinds, such as schemata and ideas, but the interpretive tradition has focused primarily on sensations, intuitions, and concepts. I follow that tradition in my discussion here. One could, however, object that the debate is not well-formed, and emphasize the importance of including, e.g., schemata, in the discussion of the relationship between concept possession and perceptual experience. For discussion of schemata in the generation of perceptual "images" see Matherne (Unpublished); cf. Griffith (2012); Williams (2012).

3 We might question whether it is best to translate "Vorstellung" as "representation." The reason for hesitation has largely to do with the baggage which the term "representation" carries within contemporary philosophy. It is often characterized as an "inner," causally relevant, and perhaps functionally defined state, whose semantic content allows it to play a role in the cognitive life of subject. In what follows I will translate "Vorstellung" as "representation" but I wish to highlight here the importance of not simply equating Kant's use of "Vorstellung" with a representationalist theory of perception. For an argument that Kant does not endorse such a theory see McLear (Forthcoming b) and \$3.1 below; cf. Gomes (2014).

${ }^{4}$ Quotations from Kant's work are from the Akademie Ausgabe, with the first Critique cited by the standard A/B edition pagination, and the other works by volume and page. Translations are from the Cambridge Editions of the Works of Immanuel Kant, general editors Paul Guyer and Allen Wood. I have, on some occasions, made slight modifications without further comment. Specific texts are abbreviated as follows: 
Kant claims that all the representations generated via sensibility are structured by two "forms" of intuition - space and time-and that all sensory aspects of our experience are their "matter" (A20/B34). The simplest way of understanding what Kant means by "form" here is that all perceivables will be such as to either have spatial features (e.g. extension, shape, location), or temporal features (e.g. being successive or simultaneous). ${ }^{5}$ So the formal element of an empirical intuition, or sense perception, will always be either spatial or temporal, while the material element is always sensory (in the sense of determining the phenomenal or "what it is like" character of experience), and tied to one or more of the five senses, or the feelings of pleasure and displeasure.

Kant ties the two forms of intuition to two distinct spheres, the inner and the outer. The outer concerns the spatial world of particular material objects while the inner concerns temporally ordered states of mind. Space is thus the form of "outer sense" while time is the form of "inner sense" (A22/B37; cf. An 7:154). In the Transcendental Aesthetic, Kant is primarily concerned with "pure" [rein] intuition, and often only speaks in passing of the sense perception of physical bodies (e.g. A20-1/B35). However, Kant more clearly links the five senses with intuition in the 1798 Anthropology from a Pragmatic Point of View, in the section entitled "On the Five Senses."

Sensibility in the cognitive faculty (the faculty of intuitive representations) contains two parts: sense and the imagination...But the senses, on the other hand, are divided into outer and inner sense (sensus internus); the first is where the human body is affected by physical things, the second is where the human body is affected by the mind (An 7:153).

\footnotetext{
An: Anthropology from a Pragmatic Point of View

C): Critique of Judgment

G: Groundwork for the Metaphysics of Morals

JL: Jäsche Logic

LL: Lectures on Logic

NM: Attempt to Introduce the Concept of Negative Magnitudes into Philosophy

OD: On a Discovery Whereby any New Critique of Pure Reason is to be Made Superfluous by an Older

One

Pr: Prolegomena to any Future Metaphysics

R: Notes and Fragments

5 There are complications here that I cannot go into, concerning whether or how spatial objects might be represented as standing in temporal relations with one another given that "Time can no more be intuited externally than space can be intuited as something in us" (A22-3/B37). Kant goes on to say that outer objects are temporally related only "mediately", in virtue of their representations being temporally related in inner sense (A34/B50-1). Thus, though outer objects may be said to stand in temporal relations, time is not an a priori condition of the appearance of an outer object in the way that space is. Whether this means that objects in space only seem to be in time, in virtue of their representations being intuited as standing in temporal relations in inner sense, goes beyond what I can discuss here. For discussion see Van Cleve (1999), ch. 5; Brook (2013).
} 
Kant characterizes intuition generally in terms of two characteristics-viz. immediacy [Unmittelbarkeit] and particularity [Einzelheit] (cf. A19/B33, A68/B93; JL 9:91). This is in contrast to the mediacy and generality [Allgemeinheit] characteristic of conceptual representation (A68/B93; JL 9:91).

Kant contrasts the particularity of intuition with the generality of concepts in the "stepladder" passage (see the first quote above). But the specific remark he makes is that a concept is related to its object via "a mark, which can be common to many things" (A320/B377) and this suggests that intuition, in contrast to concepts, puts a subject in cognitive contact with features of an object that are not had by other things. ${ }^{6}$ Spatiotemporal properties seem like excellent candidates for such features. ${ }^{7}$ But pehaps any non-repeatable, non-universal feature of a perceived object will do. ${ }^{8}$

Does the occurrence of an intuition count as having an experience, in our contemporary sense of a cognitively significant mental event or state with a particular (sensemodal) phenomenal character? ${ }^{9}$ More generally, does Kant's usage of terms like "perception" [Wahrnehmung] and "experience" [Erfahrung] cleanly match up with ours? Given how slippery these terms are, even in their everyday usage, we should be somewhat cautious in thinking that they do. At least two worries loom large here. First, we might worry that disputes concerning the necessary conditions of having a "perception" or an "experience" are merely verbal. Second, we might worry that the concepts $<$ perception $>$ and $<$ experience $>$ are not well-defined, and thus that no substantive dispute should hang on either of them. For the purposes of this paper, I shall take the concepts $<$ perception $>$ and $<$ experience $>$ as sufficiently well-defined that we can credibly

6 There is a further controversy here as whether the immediacy of intuition is compatible with an intuition's relating to an object by means of marks or whether relation by means of marks entails mediacy, and thus that only concepts relate to objects by means of marks. See Smit (2000) for discussion.

7 This is true at least if we assume that spatio-temporal location is sufficient to individuate one thing from another. Certainly Kant thought this the case; cf. B327-8.

8 For example, intuition may give a subject perceptual access to the tropes characterizing an object. For the suggestion of a view along these lines see Smit (2000); Grüne (2009), 50, 66-70.

9 A note about the use of "cognitive" here. There is a difference between mental states which possess phenomenal characteristics but no seeming objective cognitive features, such as what happens in "seeing stars" or being poked in the eye, etc., and states that are both phenomenally rich and cognitive, such as having a perceptual experience as of some object in one's environment, such as a tree or animal. There is, of course, a serious question as to whether or how these two kinds of states might be related. I shall take it that Kant's usage of "intuition" is meant to designate a cogntive state rather than a state which merely possesses phenomenal character. The latter seems to most consistently be designated by the term "sensation" [Empfindung], or more precisely, by "feeling" [Gefüh/]. This is especially clear in Kant's discussion of sensation and feeling in the third Critique; cf. CJ 5:189, 203-6. Whether and how such cognitive and non-cognitive states are related is a complex issue, and we'll touch on it further in the discussion of conceptualism below. 
dispute over the necessary conditions for their instantiation. ${ }^{10}$ But I do think that it is necessary to say something about the possibility of a merely verbal dispute concerning the conditions for the occurrence of a perceptual experience.

Kant obviously makes a distinction between "experience" [Erfahrung] and "intuition" [Anschauung]. He is clear that "experience," in his sense of an "empirical cognition" [empirische Erkenntnis], includes conceptual synthesis, since such synthesis is what binds the various elements of an empirical cognition together such that they are nonarbitrarily connected (cf. B12, B161, B201, B218, B233). ${ }^{11}$ As a result, we cannot understand the (non)-conceptualism debate as concerning "experience" in Kant's sense of the term. Non-conceptualist interpreters all concede that Kant's usage of "experience" [Erfahrung] and "empirical cognition" [empirische Erkenntnis] typically is meant in a way that assumes some sort of cognitive contribution by the understanding.

The difficulties that result in trying to pin down Kant's use of "experience" [Erfahrung] have not gone unnoticed in the literature. ${ }^{12}$ For example, Hannah Ginsborg has argued that Kant's argument that the understanding must be active in the generation or constitution of "Erfahrung" is potentially ambiguous between designating sense modal specific states of phenomenal consciousness-"sense impressions"—and full-blown perceptual judgments. But it seems clear that Kant himself took the terms"intuition" [Anschauung], "perception" [Wahrnehmung], and "experience" [Erfahrung] to designate different things. ${ }^{13}$ Intuition is a relation to an "undetermined" [unbestimmt] object or an "appearance" [Erscheinung] (A20/B34). Intuition is distinguished from "perception" [Wahrnehmung] by virtue of the subject's being conscious of the "content" [Inhalt] of the intuition (more on the notion of "content" below) ( $\operatorname{Pr} 4: 300$; cf. A99, A119-20, B162, B202-3). ${ }^{14}$ Finally, "experience" [Erfahrung] involves the synthesis of perceptions [Wahrnehmungen] via application of (or perhaps guidance by) the categories. "Experience is cognition through connected perceptions [durch verknüpfte

\footnotetext{
${ }^{10}$ See Hinton (1973); Byrne (2009) for contemporary discussion of worries concerning the notion of an "experience".

11 As Kant says in the Prolegomena, "Experience consists in the synthetic connection [Verknüpfung] of appearances (perceptions) in a consciousness, insofar as this connection is necessary" ( $\operatorname{Pr} 4$ :305; cf. 4:275; B147, B218, B227).

${ }^{12}$ See the discussion in Van Cleve (1999), 74-6; Ginsborg (2006b).

${ }^{13}$ Thanks to Clinton Tolley for discussion concerning these and related points.

${ }^{14}$ What exactly is intended by Kant's use of "conscious" [Bewußt] and "consciousness" [Bewußtsein] further complicates matters. Significantly, for our purposes, we cannot take for granted that Kant means to indicate what we typically mean in using the term-viz. "phenomenal consciousness" or "what it is like" to have the relevant experience. Kant typically uses the term in the Leibniz-Wolff sense in which it indicates the extent to which the representing subject can distinguish between objects or the parts of objects. See Wunderlich (2005); La Rocca (2008a), La Rocca (2008b); Grüne (2009), ch.1; Sturm and Wunderlich (2010); McLear (2011) for discussion.
} 
Wahrnehmungen]" (B161; cf. B218; Pr 4:300). This threefold distinction is also confirmed in the headings to the first three chapters of the Principles of the first Critique, in which Kant distinguishes between the "Axioms of Intuition", the "Anticipations of Perception", and the "Analogies of Experience". If Kant weren't thinking that the terms the terms "intuition" [Anschauung], "perception" [Wahrnehmung], and "experience" [Erfahrung] designated distinct mental states, then it would be difficult to understand why he ordered a central part of his architectonic around them.

There is also a prima facie tension between the suggestion above, that we distinguish "intuition" from "perception"—i.e "Wahrnehmung"—and Kant's remark in the Stufenleiter passage quoted above, that "perception" [perceptio] is the category of "representation with consciousness", in which he includes intuition. One difficulty is that "Wahrnehmung", "perceptio", and "Perzeption" are all typically translated in English using "perception", while it is unclear that all these terms mean the same thing for Kant, or that they mean what we mean, using "perception" in its contemporary English sense. But the difficulty isn't just related to the problem of English translation; rather, the text of the Stufenleiter seems to define intuition in terms of being a conscious representation (and thus a "perceptio"), but I suggested above the Kant distinguishes intuition from Wahrnehmung by appeal to the presence of consciousness in the latter but not the former.

One possible move in resolving this tension is to say that the notion of "consciousness" in the Stufenleiter concerns consciousness of the representation, rather than, specifically, its content. Intuitions, on this reading, would be conscious representations, but the sense in which they are conscious differs from that of a Wahrnehmung. There is already ground for such a distinction in Kant's differentiation between the consciousness inherent in the awareness of a representation-its "clarity" [Klarheit], which requires only that the representation suffice for distinguishing an object from othersand the consciousness inherent in the awareness of the content of a representation-its "distinctness" [Deutlichkeit], which requires that one clearly represent all the different parts of the content of the representation (or the parts of its corresponding object) (An 7:137-8; cf. JL 9:34; R 643, 15:283; R 1709, 16:89). ${ }^{15}$ This means of resolving the issue is perhaps made even more attractive by Kant's remark in the Anthropology that,

distinctness alone makes it possible that an aggregate [Summe] of representations becomes a cognition [Erkenntnis], in which order is thought in this manifold, because every conscious combination [Zusammensetzung mit Bewußtsein] presupposes unity of consciousness, and consequently a rule for the combination. $(7: 138)$

${ }^{15}$ There are complications, however, in simply equating clarity and consciousness; cf. B414-15, note. Kant also seems quite happy to entertain the possibility of unconscious or "obscure" [Dunke/] intuitions (An 7:135); cf. Wunderlich (2005), 141-2; Grüne (2009), ch. 1.3. 
This passage suggests that an intuition, of itself, is at best conscious in the sense of being clear [klar]. When an intuition is apprehended in an act of Wahrnehmung (cf. Pr 4:300), its content is brought together in such a way that it becomes (at least to some degree) distinct [deutlich], and thus a candidate for cognition. In this manner, we seem able to resolve the tension between the account of the difference between intuition and Wahrnehmung offered above and Kant's remarks in the Stufenleiter. ${ }^{16}$

Given the difficulty of providing a precise account of how Kant's terminology maps onto contemporary usage (assuming that it does at all), I focus below on what I take to be a central aspect of the contemporary debate between conceptualist and nonconceptualist interpretations of Kant-viz. whether intuitions, understood by this debate as mental states which are both cognitive, and have sense-modal specific phenomenal character, depend on (and in what way they depend on) acts of the understanding. The emphasis on intuition is grounded in Kant's texts insofar as Kant repeatedly cites empirical intuition as that which is our first or primary means of being sensorily related to actual objects (Pr 4:283; cf. Pr 4:350; B160; A180/B222; OD 8:217). I shall freely use the terms "perception", "experience", and "perceptual experience" to describe the mental states Kant designates by "intuition" [Anschauung], so long as it is understood that these English terms are meant in our contemporary usage, not necessarily Kant's.

So I use "outer intuition" (or where context permits, simply "intuition") to indicate, unless otherwise noted, the perception (i.e. the English term for cognitive sensory consciousness) of an existence distinct from the subject. "Inner" intuition, in contrast, is the awareness of the subject's existence, and a particular mode thereof (e.g. feeling warm, hungry, etc.). Both are forms of experience in the English sense of the termviz. a cognitive mental state or event with a particular phenomenology based on one of the five senses. But, as noted above, neither inner nor outer intuition is sufficient for experience [Erfahrung] in Kant's sense of the term. Kant's notion of an experience requires conceptual and apperceptive capacities which engender an awareness of lawful relations between consciously perceived objects, properties, states, or events.

The question to which we now turn concerns the conditions under which a mental state type that Kant designates as "intuition" [Anschauung] requires or otherwise presupposes mental acts of synthesis (or at least the capacity for such acts) by the understanding.

\section{Kantian Non-Conceptualism}

At the heart of non-conceptualist readings of Kant stands the denial that mental acts of synthesis carried out by the understanding are necessary for the occurrence of cognitive mental states of the type which Kant designates by the term "intuition" [Anschauung].

${ }^{16}$ Thanks to Sam Rickless for encouraging clarity on this point. 
Though it is controversial as to what might be considered the "natural" or "default" reading of Kant's mature critical philosophy, there are at least four considerations which lend strong support to a non-conceptualist interpretation of Kant's mature work.

First, as several scholars have noted, Kant repeatedly and forcefully states that in our cognition there is a strict division of cognitive labor - objects are given by sensibility and thought via the understanding. ${ }^{17}$ As Robert Hanna has argued, when Kant discusses the dependence of intuition on conceptual judgment in the Analytic of Concepts, he is specifically talking about cognition rather than what we would consider to be perceptual experience. ${ }^{18}$

Second, Kant characterizes the representational capacities characteristic of sensibility as more primitive than those characteristic of the understanding (or reason), and as plausibly part of what humans share with the rest of the animal kingdom. ${ }^{19}$ For example, Robert Hanna construes Kant's distinction between the faculties of sensibility and understanding as capturing the difference between the "sub-rational" powers of the mind that we share with non-human animals, and the "rational or higher-level cognitive powers" that are special to human beings. ${ }^{20}$

If one were to deny that, according to Kant, sensibility alone is capable of producing mental states that were cognitive in character then it would seem that any animal which lacks a faculty of understanding, and thus the capacity for conceptual synthesis, would thereby lack any capacity for genuinely perceptual experience. The mental lives of non-rational animals would thus, at best, consist of non-cognitive sensory states which causally correlate with changes in the animal's environment. Aside from what we would now consider to be an unappealing and implausible characterization of the cognitive capacities of animals, this reading also faces textual hurdles. Kant is on record in various places as saying that animals have sensory representations of their environment (CP) 5:464; LM 28:449; cf. An 7:212), that they have intuitions (LL 24:702), and that they are acquainted with objects though they do not cognize them (JL 9:64-5). ${ }^{21}$

If Kant's position is that synthetic acts carried out by the understanding are necessary for the cognitive standing of a mental state, then Kant is contradicting fundamental

${ }^{17}$ Hanna (2005); Allais (2009); McLear (2011); Hanna (2011a); Tolley (2013); McLear (Forthcoming a), McLear (Forthcoming b).

${ }^{18}$ See the discussion of Kant's "togetherness principle" and it's significance for setting the conditions on objectively valid judgment in Hanna (2005), 265-7.

${ }^{19}$ Kant connects the possession of a faculty of sensibility to animal nature in various places, e.g. A546/B574, A802/B830; An 7:196.

${ }^{20}$ Hanna (2005), 249; cf. Allais (2009); McLear (2011), McLear (Forthcoming a), §3.

${ }^{21}$ For further discussion see Naragon (1990); Allais (2009); McLear (2011). For some defense of the conceptualist position see McDowell (1996), chs. 3 \& 6; Ginsborg (2006b), Ginsborg (2006a); Ginsborg (2008); Gomes (2014). 
elements of his own position in crediting intuitions (or their possibility) to non-rational animals.

Third, any position which regards perceptual experience as dependent upon acts of synthesis carried out by the understanding must also construe the "pure" intuitions of space and time as dependent upon acts of synthesis. ${ }^{22}$ However, Kant's discussion of space (and analogously, time) in the third and fourth arguments (fourth and fifth in the case of time) of the Metaphysical Exposition of Space in the Transcendental Aesthetic seems incompatible with such a proposed relation of dependence.

Kant's point in the third and fourth arguments of the Metaphysical Exposition of space (and similarly of time) is that no finite intellect could grasp the extent and nature of space as an infinite whole via a synthetic process moving from part to whole. If the unity of the forms of intuition were also something dependent upon intellectual activity, then this unity would necessarily involve the discursive (though not necessarily conceptual) running through and gathering together of a given multiplicity (presumably of different locations or moments) into a combined whole, which Kant believes is characteristic of synthesis generally (A99).

But Kant's arguments in the Metaphysical Expositions of space and time require that the fundamental basis of our representation of space and time does not proceed from a grasp of the multiplicity of features of an intuited particular to the whole that has those features. Instead the form of pure intuition constitutes a representational whole that is prior to that of its component parts (cf. CJ 5:407-8, 409). ${ }^{23}$

Hence, Kant's position is that the pure intuitions of space and time possess a unity wholly different from that given by the discursive unity of the understanding (whether it be in conceptual judgment or the intellectual cum imaginative synthesis of intuited objects more generally). The unity of aesthetic representation-characterized by the forms of space and time- - has a structure in which the representational parts depend on the whole. The unity of discursive representation-representation where the activity of the understanding is involved-has a structure in which the representational whole depends on its parts. ${ }^{24}$

Finally, there has been extensive discussion of the non-conceptuality of intuition in the secondary literature on Kant's philosophy of mathematics. For example, Michael Friedman has argued that the expressive limitations of the prevailing logic in Kant's time required the postulation of intuition as a form of singular, non-conceptual representa-

${ }^{22}$ This position is forcefully articulated in Longuenesse (1998), ch. 8; see also Griffith (2012); Friedman (2012).

${ }^{23}$ Kant's argument here is directed very much against the Leibnizian view that all representation is purely conceptual. For further discussion see Adams (1994), ch. 9; Janiak (2012).

${ }^{24}$ For much more extensive discussion of this issue see McLear (Forthcoming a); cf. Messina (2014); Onof and Schulting (Forthcoming). 
tion. ${ }^{25}$ Charles Parsons and Emily Carson have argued that space must be given in a phenomenological manner as an original, non-conceptual representation in order that we be able to demonstrate the real possibility of constructed mathematical objects as required for geometric knowledge. ${ }^{26}$ Ultimately, however, there are difficulties in assessing whether Kant's philosophy of mathematics can have relevance for the conceptualism debate, since the sense in which intuition must be non-conceptual in accounting for mathematical knowledge is not obviously incompatible with claiming that intuitions themselves (including pure intuition) are dependent upon a conceptually-guided synthesis. $^{27}$

The non-conceptualist reading is thus clearly committed to allowing that sensibility alone provides, in a perhaps very primitive manner, objective representation of the empirical world. Sensibility is construed as an independent cognitive faculty, which humans share with other non-rational animals, and which is the jumping-off point for more sophisticated conceptual representation of empirical reality.

\section{Kantian Conceptualism}

In the introduction I characterized conceptualism as claiming that there is a dependence relation between a subject's having conscious sensory experience of an objective world, and the repertoire of concepts possessed by the subject and exercised in acts by her faculty of understanding.

As a first pass at sharpening this formulation, we may understand conceptualism, as it appears in the scholarly literature on Kant, as a thesis consisting of two claims: (i) sense experience has correctness conditions determined by the "content" of the experience; (ii) the content of an experience is a structured entity whose components are concepts. Let's take these in turn.

${ }^{25}$ Friedman (1992), ch. 2; cf. the discussion of the non-conceptual conditions of judgments of equality in Anderson (2005), 54-8 and the discussion of the representation of homogeneous units in Sutherland (2008).

${ }^{26}$ Parsons (1964); Parsons (1992); Carson (1997); Carson (1999); cf. Hanna (2002). For a general overview of related issues in Kant's philosophy of mathematics see Shabel (2006) and the works cited therein at p. 107 , note 29 .

${ }^{27}$ Michael Friedman (Friedman (2012)) has recently articulated such a position; cf. Longuenesse (1998). If, as Friedman argues, Kant's notion of the conceptual is tied to his logic, then, as we move away from syllogistic logic post-Frege, there may be notions of the conceptual that are compatible with Kant's views in mathematics. For discussion see MacFarlane (2002); Anderson (2004), Anderson (2005). 


\subsection{Content \& Correctness}

An important background assumption governing the conceptualism debate construes mental states as related to the world cognitively (as opposed to merely causally) if and only if they possess correctness conditions. That which determines the correctness condition for a state is that state's "content".

Suppose, for example, that an experience $\mathrm{E}$ has the following content $\mathrm{C}$ :

C: That cup is white.

This content determines a correctness condition V:

V: S's experience $E$ is correct iff the cup visually presented to the subject as the content of the demonstrative is white and the content $C$ corresponds to how things seem to the subject to be visually presented.

Here the content of the experiential state functions much like the content of a belief state to determine whether the experience, like the belief, is or is not correct.

A state's possession of content thus determines a correctness condition, in virtue of which we can construe the state as mapping, mirroring, or otherwise tracking aspects of the subject's environment.

Perhaps the most prominent recent interpretation of Kant as endorsing the content assumption is found in John McDowell's Mind and World. McDowell's project there is to show, given certain presuppositions concerning the nature of justification, how it is that experience can play a justificatory and not merely causal role in the fixation of belief. In the course of this argument McDowell articulates very clearly a commitment to construing representational content as the kind of thing that is correct or incorrect. He says,

The very idea of representational content brings with it a notion of correctness and incorrectness: something with a certain content is correct, in the relevant sense, just in case things are as it represents them to be. I can see no good reason not to call this correctness "truth." But even if, for some reason, we reserve that title for correctness in this sense when it is possessed by things with conceptual content, it seems a routine thought that there can be rational connections between the world's being as a possessor of one bit of content represents it and the world's being as a possessor of another bit of content represents it, independently of what kind of content is in question. ${ }^{28}$

${ }^{28}$ McDowell (1996), 162. Many of McDowell's interlocutors share similar views. Cf. Evans (1982), 202; Peacocke (1992), 55, 65; Burge (2003), 506. 
McDowell explains the close connection between the idea of representational content and that of correctness in terms of the normative character of any world-directed mental state, a paradigmatic instance of which is judging that something is the case. He says,

To make sense of the idea of a mental state's or episode's being directed towards the world, in the way in which, say, a belief or judgement is, we need to put the state or episode in a normative context. A belief or judgement to the effect that things are thus and so- - a belief or judgement whose content (as we say) is that things are thus and so-must be a posture or stance that is correctly or incorrectly adopted according to whether or not things are indeed thus and so. (If we can make sense of judgement or belief as directed towards the world in that way, other kinds of content-bearing postures or stances should easily fall into place). ${ }^{29}$

Here McDowell claims that beliefs and judgments have a particular way of disclosing the world to a subject and that this is a way in which we might understand worlddirected mental states more generally. He further claims that the way in which a mental state is directed at the world is in terms of its possessing a correctness condition concerning how the world in fact is. McDowell then relates his understanding of such world-disclosing or world-directed states to perceptual experience.

We should understand what Kant calls "intuition" — experiential intakenot as a bare getting of an extra-conceptual Given, but as a kind of occurrence or state that already has conceptual content. In experience one takes in, for instance sees, that things are thus and so. That is the sort of thing one can also, for instance, judge. ${ }^{30}$

McDowell here utilizes Kant's term "intuition" [Anschauung] which McDowell equates with "experiential intake." So he endorses the idea that intuition has content (being necessary for our "taking in" that something is the case), and that it is in virtue of this content that the experiential state, together with the world, is either correct or incorrect. From this we can conclude that, according to McDowell, intuitions have representational content, that this entails that such content is assessable for its correctness, and that intuitions with content are thereby mental states assessable for their correctness. Hence, McDowell's interpretation clearly understands Kant as endorsing a version of the content assumption.

${ }^{29}$ McDowell (1996), xi-xii.

${ }^{30}$ McDowell (1996), 9. 
Many non-conceptualist opponents of McDowell's interpretation nevertheless share with him an endorsement of the content assumption. ${ }^{31}$ However, they differ with him in at least one of two ways. First, the content of an experience which sets its correctness conditions is attributed to the experience regardless of what, if any, other conceptual capacities the subject may have. Non-conceptual contents are thus meant to capture aspects of the perceiving subject's experience that may well outrun the subject's own capacities for articulation. ${ }^{32}$

Second, proponents of non-conceptualist readings of content may construe nonconceptual contents as correct in a manner that is altogether distinct from conceptual contents, which are true or false depending on whether the conditions set out by the concepts constituting the content are satisfied. In contrast, non-conceptual content, much like the content of a map or a recording, is accurate or inaccurate. It thus admits of degrees of approximation. ${ }^{33}$

Thus, for many non-conceptualists, while it is still the case that a subject's mental states only count as representational in virtue of possessing correctness conditions, the nature and articulation of these correctness conditions may well differ radically from those set out by conceptualism.

We can see these two features of non-conceptualism at work in an interpretation of Kant that is, in many ways, directly opposed to McDowell's conceptualism. Robert Hanna has argued that, for Kant, sensible intuitions possess wholly non-conceptual representational content. We can see this in two quotes from Hanna, the first of which describes the non-conceptualist position and attributes it to Kant, while the second articulates in greater detail the kind of representational content Hanna thinks is present in perceptual experience.

Non-conceptualism holds that non-conceptual content exists and is representationally significant... Non-conceptual cognitive content in the contemporary sense is, for all philosophical intents and purposes, identical to intuitional cognitive content in Kant's sense. ${ }^{34}$

${ }^{31}$ Many, but not all. See Tolley (2011), Tolley (2013); McLear (Forthcoming b).

32 Endorsement of this thesis sometimes goes under the name 'state non-conceptualism' or 'relative nonconceptualism.' See Heck (2000); Speaks (2005); cf. Allais (2009); Hanna (2005), Hanna (2008), Hanna (2011b).

${ }^{33}$ Cf. Burge (2003). This conception of non-conceptual content also goes under name 'content nonconceptualism' or 'absolute non-conceptualism.' See, again, Heck (2000); Speaks (2005).

${ }^{34}$ Hanna (2005), 248. 
essentially non-conceptual content is either accurate or inaccurate, and as I have suggested, inherently poised for use in the intentional actions of conscious animals. ${ }^{35}$

We can thus see that for Hanna, intuitional content is non-conceptual but nevertheless representational-it expresses an accuracy condition in virtue of which the mental state represents some portion of the mind-independent world. Hanna's position (both on its own and as attributed to Kant) regards this nonconceptual content as essentially veridical, indexical, and context dependent. ${ }^{36}$ But the basic presumption which drives Hanna's non-conceptualism is the same as that of McDowell's conceptualism. A mental state counts as a state of perceptual awareness-i.e. a "world-directed" state-only in virtue of having a representational content which sets a correctness condition for the state. Hence, Hanna, like McDowell, articulates an interpretation which endorses the content assumption.

I take it that McDowell's and Hanna's views are representative of two extremes regarding interpretations of Kant understanding of the content of intuition. McDowell, at least in the discussion in Mind and World, argues that intuition is through and through conceptual. That is, McDowell understands the representational content of perception as the same kind of content as is found in beliefs or thoughts. So the content of an experience is a conceptually structured, truth-evaluable proposition. ${ }^{37}$ Hanna, in contrast, argues that intuition has absolute non-conceptual content-it has a structure essentially different in nature from that of conceptual content. ${ }^{38}$

Hanna and McDowell articulate the basic shape of much recent debate concerning

${ }^{35}$ Hanna (2008), 58.

${ }^{36}$ Hanna (2006), chs. 1-2; Hanna (2011b); cf. Howell (1973); Pereira (2013) .

${ }^{37}$ McDowell has since changed his view. A more current specification of it states that intuition is not propositional in structure though it nevertheless possesses conceptual content. See McDowell (2008). However, since McDowell still construes the content of intuition as intentional and conceptual, bringing with it a normative notion of correctness, I consider even his more current statements to be an endorsement of the content assumption. Cf. McDowell (2013), where he explicitly says that it is "in virtue of having content as they do that perceptual experiences put us in such [i.e. cognitive] relations to things" (p. 144).

${ }^{38}$ Hanna (2011a), 354; cf. Hanna (2005). 
the interpretation of Kant's views concerning perceptual experience. ${ }^{39}$ So whether a perceptual experiential state has conceptually structured content (McDowell), or nonconceptually structured content (Hanna), it is in virtue of the state's aiming at a way the world might be, and thus having a correctness condition, that the state counts as a form of perceptual awareness.

There are reasons for questioning whether Kant endorses the content assumption as I've articulated it above. ${ }^{40}$ Kant seems to deny several claims which are integral to it. First, in various places he explicitly denies that intuition, or the deliverances of the senses more generally, are the kind of thing which could be correct or incorrect (A2934/B350; An §11 7:146; cf. LL 24:83ff, 103, 720ff, 825ff). Second, Kant's conception of representational content requires an act of mental unification ( $\operatorname{Pr} 4: 304$; cf. JL $\$ 17$ 9:101; LL 24:928), something which Kant explicitly denies is present in an intuition (B129-30; cf. B176-7). ${ }^{41}$ Finally, Kant's "modal" condition on cognition, that it provide a demonstration of what is really actual rather than merely logically possible, seems to preclude an endorsement of the content assumption. However, for the purposes of understanding the conceptulism debate, we will assume that Kant does endorse the content assumption. The question then is how to understand the nature of the content so understood.

\subsection{Conceptual Content}

In addition to the content assumption, I defined conceptualism as committed to the content of intuition being completely composed of concepts. Against this, Clinton Tolley (Tolley (2013), Tolley (2011)) has argued that the immediacy/mediacy distinction between intuition and concept entails a difference in the content of intuition and concept.

\footnotetext{
${ }^{39}$ There are a great many other ways to articulate the notion that intuition has content within the limits set by Hanna and McDowell. For example, there are coherent interpretations which deny that intuition has conceptual content, but assert that it is the result of an imaginative synthesis, and hold that the images which constitute experiential consciousness are constructions according to conceptual rules. Hence, insofar as the images purport to be representational they must be attributed a content determined by the rules of their construction. In my terms, this amounts to a variation of the Content assumption. See Longuenesse's discussion of concepts as rules for sensible synthesis. Longuenesse (1998), 50ff. See also Anderson (2001); Land (2011); Matherne (Unpublished). Watkins (2008), 519-20 also suggests an imagistic view, though it is not fully articulated. Other views that seem compatible with such an account include Strawson (1966); Strawson (1970); Sellars (1968); Ginsborg (2006b); Ginsborg (2006a). Schulting (2012) presents a recent and helpful overview of many of the relevant issues.

${ }^{40}$ See McLear (Forthcoming b) for more extensive discussion.

${ }^{41}$ Kant does not, however, deny that intuition has "content" [Inhalt $]$ in some sense other than that of a correctness condition. For discussion see Tolley (2011), Tolley (2013); McLear (Forthcoming b).
} 
if we understand by "content" ... a representation's particular relation to an object...then it is clear that we should conclude that Kant accepts nonconceptual content. This is because Kant accepts that intuitions put us in a representational relation to objects that is distinct in kind from the relation that pertains to concepts. I argued, furthermore, that this is the meaning that Kant himself assigns to the term "content". (Tolley (2013), 128)

Insofar as Kant often speaks of the "content" [Inhalt] of a representation as consisting in a particular kind of relation to an object (Tolley (2013), 112; cf. B83, B87) Tolley thus gives us a kind of "short argument" for a non-conceptualist reading of Kant:

1. The content of a cognition (whether intuition or concept) consists in-i.e. is nothing but-a relation to an object

2. Concepts and intuitions relate to objects in different ways-viz. mediately and immediately

3. $\therefore$ The content of intuition is different from the content of concepts-i.e. it is non-conceptual

Tolley's argument gives us good reason to reject the idea that intuition could have, in Kant's sense of the term, a concept as its "content". ${ }^{42}$ However it does not demonstrate that the content of what Kant calls an intuition is not something that we would construe as conceptual, in a wider sense of that term. For example, both pure and complex demonstrative expressions have conceptual form (e.g. that color, this person), but are not, in Kant's terms, "conceptual" since they do not exhibit the requisite generality which, according to Kant, all conceptual representation must. ${ }^{43}$

\subsection{Conceptualism \& Synthesis}

If it isn't textually plausible to understand the content of an intuition in conceptual terms (at least as Kant understands the notion of a concept) then what would it mean to say that Kant endorses conceptualism with regard to experience? The most plausible interpretation, endorsed by a wide variety of interpreters, reads Kant as arguing that the generation of an intuition, whether pure or sensory, depends at least in part on the activity of the understanding. On this way of carving things, conceptualism does not consist in the narrow claim that intuitions have concepts as contents or components, but rather consists in the broader claim that the occurrence of an intuition depends at

${ }^{42}$ For opposing views see Willaschek (1997); Griffith (2012); Engstrom (2006).

${ }^{43}$ For further discussion see McLear (Forthcoming b), §5.2; Thompson (1972). 
least in part on the discursive activity of the understanding. ${ }^{44}$ The specific activity of the understanding is that which Kant calls "synthesis", the "running through, and gathering together" of representations (A99). ${ }^{45}$

What's more, the fact that intuitions are generated according to acts of synthesis directed by or otherwise dependent upon conceptual capacities provides some basis to claim that whatever correctness conditions might be had by intuition must be in accord with the conceptual synthesis which generated them. This seems nicely in line with Kant's much quoted claim,

The same function that gives unity to the different representations in a judgment also gives unity to the mere synthesis of different representations in an intuition, which, expressed generally, is called the pure concept of understanding. (A79/B104-5)

The link between intuition, synthesis in accordance with concepts, and relation to an object is made even clearer by Kant's claim in $\$ 17$ of the B-edition Transcendental Deduction that,

Understanding is, generally speaking, the faculty of cognitions. These consist in the determinate relation of given representations to an object. An object, however, is that in the concept of which the manifold of a given intuition is united. (B137; emphasis in the original)

However else we are to understand this passage, Kant here indicates that the unity of an intuition necessary for it to stand as a cognition of an object requires a synthesis by the concept <object $>$. In other words, cognition of an object requires that intuition be unified by an act or acts of the understanding.

According to the conceptualist interpretation we must understand the notion of a representation's content as a relation to an object, which in turn depends on a conceptually guided synthesis. So we can revise our initial definition of conceptualism to read it as claiming that (i) the content of an intuition is a kind of relation to an object; (ii)

${ }^{44}$ McLear (Forthcoming a) calls this broader position "Intellectualism", so as to emphasize the importance of the understanding's activity, rather than the specific conceptual content of that activity.

${ }^{45}$ See Grüne (2009), ch. 2 for an alternative taxonomy. Grüne distinguishes "judgment-theoretic" [Urteilstheoretik] from "conceptualist" [Konzeptualist] interpretations on the basis of whether the interpretation construes the intuitive representations generated by sensory synthesis in terms of, or implying, judgment (Grüne (2009), 111-12). However, she and I agree that such "judgment-theoretic" views are not definitive of a broadly conceptualist interpretation, and that whether one takes Kant as arguing that intuition depends on a conceptually-guided synthesis remains a significant difference between conceptualist and non-conceptualist interpretations (Grüne (2009), §2.4; cf. Grüne (2008)). So I take the discussion here to be broadly congenial to her own. 
the relation to an object depends on a synthesis directed in accordance with concepts; (iii) synthesis in accordance with concepts sets correctness conditions for the intuition's representation of a mind-independent object. ${ }^{46}$

\section{Objections}

One of the main criticisms of the conceptualist reading of Kant is that it seemingly commits him to the position that perceptual experience is constrained by the subject's repertoire of concepts. However, Hannah Ginsborg has argued that Kant's conceptualism need not be construed in such a way. ${ }^{47}$ Instead,

there is room for a less demanding conception of what it is for understanding to be involved in perceptual synthesis, a conception which does not require that any concepts be grasped antecedently to engaging in synthesis. On this conception, to say that synthesis involves understanding is simply to say that it involves a consciousness of normativity...I want to claim that this consciousness of normativity is possible without the subject's first having grasped any concept governing her synthesis, and, more specifically, without her synthesis needing to be guided by any concept. (Ginsborg (2008), 71)

According to Ginsborg, we need not read the conceptualist as making the strong claim that perceptual experience is constrained by conceptual repertoire that the subject brings with them to experience. Instead, we need merely see the issue of conceptualization as one in which the subject combines an association of some bundle of sense impressions with the sense that she is associating them as she ought, and it is this consciousness of the normativity of one's combination that is responsible "for the objectdirected character of our perceptions" (Ginsborg (2008), 74). Hence, if Ginsborg is correct, one of the main sources for objecting to conceptualist readings of Kant-viz. their supposed denial that non-rational animals enjoy perceptual experiences—would be removed. ${ }^{48}$

${ }^{46}$ One might worry here about the object of perceptual hallucination. I set this issue largely to one side, though it is compatible with the account given above that the "objects" to which one is immediately related in perception are always "intentional" objects. See Aquila (1983); Pereboom (1988); Longuenesse (1998), 20-6; Aquila (2003), Aquila (2008); Grüne (2009), 42.

${ }^{47}$ For alternative construals of the conceptuality of experience that also see themselves as compatible with the claim that experience is primitive see Gomes (2014); Gomes (Manuscript); Land (2011).

${ }^{48}$ Ginsborg's position has been criticized by scholars on either side of the conceptualism debate. See Grüne (2008); Allais (2009), 401. 
Perhaps the most obvious objection to the non-conceptualist reading of Kant stems from his famous statement that,

Intuition [Anschauung] and concepts [Begriffe] therefore constitute the elements of all our cognition [Erkenntnis]...Thoughts without content [Inhalt] are empty, intuitions without concepts are blind. . . . The understanding is not capable of intuiting anything, and the senses are not capable of thinking anything. Only from their unification can cognition arise. (A5051/B74-75; my emphasis)

The so-called "blindness" problem raises two issues. First, that intuitions without concepts or conceptual synthesis are not intentional states, and so cannot provide the mind with relation to an object. ${ }^{49}$ Second, that we cannot even identify the cognitive contribution made by sensory experience independent of its conceptualization. ${ }^{50}$

Against the first point it has been argued that if Kant's concern is with the mechanism(s) that undergirds intentional states, and he thinks that possession of a faculty of understanding is a necessary condition for being in intentional states, then he would be simply confused in attributing the possibility of intentional states to non-rational animals. ${ }^{51}$ It has also been pointed out that, to the extent that Kant problematizes the issue of intentional relations, it is at best intentional relations to external mind-independent objects that are in question, and not intentional relations (such as those involved in thinking of one's own mental states) überhaupt. ${ }^{52}$

Against the second point, Lucy Allais (Allais (2009)) has forcefully argued that if we take Kant's definition of intuition (and likewise of concepts) seriously, then we must be able to identify an independent contribution of sensibility to cognition-viz. singular and immediate representation of an object-lest we fail to make sense of Kant's division between intuition and concept. ${ }^{53}$ It would also be extremely odd of Kant to deny the possibility of articulating the distinct contribution made by sensibility given that he goes so far as to organize the structure of argument in the first Critique around the distinction between those contributions made by sensibility (the Transcendental Aesthetic) and those made by the understanding (the Transcendental Logic, and in particular, the

${ }^{49}$ For a clear statement of the view that conceptual synthesis is the mechanism by which sensory states first achieve the status of intentional states see George (1981); Pereboom (1988); cf. Van Cleve (1999), 95-7.

${ }^{50}$ Falkenstein (1995); McDowell (1996). McDowell famously claims that sensibility cannot be even "notionally seperated" from contributions made by the understanding (McDowell (1996), 51). Cf. Bird (2006), ch. 7.2.

51 See Naragon (1990); Allais (2009); McLear (2011) and the references cited in notes 20 and 21 above.

${ }^{52}$ Cf. George (1981), 233 and Van Cleve's critical discussion in Van Cleve (1999), 96.

${ }^{53}$ Allais (2009), 393-4; cf. Falkenstein (1995), 63. 
Analytic). ${ }^{54}$ The claim of "blindness", it is argued, should not be interpreted as so extreme as to render unintelligible fundamental aspects of Kant's architectonic, or of his repeated statements concerning the individual cognitive roles of the faculties of sensibility and understanding. Finally, at best, the blindness problem seems to concern the difficulties involved in articulating the nature of sensory content without drawing on concepts in the process of providing the articulation. ${ }^{55}$ But this can be conceded without thereby admitting that there is no sensory content (or positive cognitive contribution) independent of conceptual articulation.

A significant further source of criticism of the non-conceptualist reading is that it at best renders ineffectual Kant's apparent strategy for demonstrating the legitimacy of the categories in the argument of the Transcendental Deduction, and at worst shows Kant to be totally confused in his argumentative strategy. ${ }^{56}$

A key text for this reading comes in the conclusion to the second or "B-edition" version of the argument of the Transcendental Deduction.

[E]verything that may ever come before our senses must stand under the laws that arise a priori from the understanding alone (B160) . . . Consequently all synthesis, though which even perception itself becomes possible, stands under the categories, and since experience is cognition though connected perceptions, the categories are conditions of the possibility of experience, and are thus also valid a priori of all objects of experience. (B161)

What this passage and its context suggest is that the culmination of Kant's argument demonstrating the legitimacy of the a priori concepts he calls the "categories" requires showing that all perception depends on a synthesis via the categories. Here, however, it is important to note that Kant is using "perception" [Wahrnehmung] in his own technical sense, as discussed in $\$ 2$ above, rather than our contemporary English sense. So he argues here that the categories are necessary for consciousness of the complex content of an intuition. But it isn't clear that this is equivalent to being necessary for having an intuition, and thus for having a sensory experience in the contemporary sense with which we've been concerned.

A further, and much discussed, text in the B-edition Transcendental Deduction is also often taken as supporting a conceptualist interpretation. There Kant says,

Space, presented as object (as we are actually required to represent it in geometry), contains more than [the] mere form of intuition-viz. it contains

\footnotetext{
${ }^{54}$ Bird (2006), 127

${ }^{55}$ Bird (2006), 129-30.

${ }^{56}$ Cf. Ginsborg (2008), 68-9; Griffith (2012). For criticism see Allais (2009); Tolley (2013); McLear (Forthcoming a).
} 
also the gathering-together [Zusammenfassung] of the manifold given according to the form of sensibility, in an intuitive representation-so that the form of intuition gives us merely a manifold, but formal intuition gives us unity of representation. In the Transcendental Aesthetic I had merely included this unity with sensibility, wanting only to point out that it precedes any concept. But this unity indeed presupposes a synthesis which does not belong to the senses, through which all concepts of space and time first become possible. For through this unity (inasmuch as understanding determines sensibility) space or time are first given as intuitions, and hence the unity of this intuition belongs a priori to space and time, and not to the concept of understanding (see \$24) (B160-1, note).

Here the conceptualist takes Kant to "complete" the argument of the Deduction by arguing that even the existence of space and time as pure intuitions depends on a synthesis by the categories. ${ }^{57}$ The conceptualist idea here is that, by making space and time themselves depend on a categorial synthesis, Kant assures his desired conclusionviz. that all possible empirical intuition must depend on the categories, and thus that all possible objects of empirical intuition must fall under the categories. The conceptualist thus takes this as proof that a non-conceptualist approach to reading the Deduction must make the argument there hopeless and Kant's strategy deeply confused. ${ }^{58}$

One thing to note about the footnote passage is that, in the first sentence, Kant explicitly invokes the notion of space as an object of geometry. But it isn't obvious that Kant identifies the conditions under which a subject may represent space geometrically with the conditions for representing space simpliciter. In fact, Kant's distinction in the footnote between the forms of intuition and formal intuition suggests that he denies any such identification. So Kant can consistently hold that the unity of the representation of the pure forms of intuition-space and time-is independent of any synthesis, while acknowledging, as he does in the last sentence of the note, that the representation of these entities as objects, as we do in the formal intuitions required for mathematics, requires a pre-conceptual synthesis carried out by the imagination. ${ }^{59}$

\footnotetext{
57 The source of this interpretation seems to be Hegel. See Hegel (1977), 69-72. For relevant discussion see Pippin (1989), 29-31; Waxman (1991), 79ff; Longuenesse (1998), ch. 8; Keller (1998), 107-12, 254; McDowell (2003), McDowell (2007); McLear (Forthcoming a); Messina (2014).

${ }^{58}$ Longuenesse (1998); Wenzel (2005); Gomes (2010); Land (2011); Griffith (2012); Gomes (2014). Not all non-conceptualists take up this challenge. Hanna (2011b) simply accepts this as a consequence of Kant's non-conceptualist position, and construes Kant as deeply divided in his own views on the matter. For objections to Hanna's position see Grüne (2011); Schulting (2012). For an extensive discussion of the B160-1 footnote and defense of a non-conceptulist reading of it see Onof and Schulting (Forthcoming).

${ }^{59}$ Cf. the discussion in McLear (Forthcoming a), §2.1.
} 
We've also seen one non-conceptulist argument, above, that Kant's argumentative strategy in the Deduction cannot depend on making the unity of intuition itself dependent on synthesis because it jeopardizes his arguments in the Transcendental Aesthetic. Such an interpretation would also directly contradict Kant's characterization of the finite nature of human intellectual activity (CJ 5:407; cf. B72; CJ 5:251-2, 253-4). ${ }^{60}$ Other non-conceptual replies to this conceptualist reading include denying that the synthesis required for the unity of perceptual intuition is itself conceptual, ${ }^{61}$ and distinguishing between the having of an intuition, and the representation of the content of an intuition — where the latter is understood as a determinate representational relation to some object. ${ }^{62}$

Finally, and perhaps most centrally for some conceptualist readings (most notably Sellars's and McDowell's), the role of concepts in the generation of perceptual experience is supposed to help explain how perception can play a justificatory rather than merely a causal role in the fixation of belief. Non-conceptualism, so the objection goes, cannot account for the justificatory role of perceptual experience in the fixation of empirical belief. Versions of this objection have often, since Wilfred Sellars's famous paper, gone under the moniker of the "Myth of the Given". ${ }^{63}$ While it is not entirely obvious how Kant's texts or arguments yield any substantive connection with the concerns articulated by Sellars, I shall suggest below three possible ways in which such a connection might be understood.

The exact nature of objections to the supposedly mythical "Given" vary. ${ }^{64}$ One objection, made by Sellars, is that justifiers for belief must have a certain kind of structureviz. a fact-like structure that mirrors the propositional structure of belief. In contrast, sensory experiences (construed as sensations) are particulars rather than facts, and so cannot play any justificatory role. ${ }^{65}$ This "premise principle", as it has been called in contemporary epistemology, thus plays a significant role in motivating the rejection of experience, insofar as it lacks representational content, as a potential justifier for be-

${ }^{60}$ For further discussion of this point see McLear (Forthcoming a).

${ }^{61}$ Rohs (2001), 220-1; Allais (2009), 395-6, 406-7; cf. Tolley (2013). Willaschek (1997) argues that intuition causally relates to its object independent of concepts, but only has intentional content given a conceptual syntheis. Hanna takes another tack and argues that sensibility has its own form of spontaneous synthesis distinct from the understanding's (cf. Hanna (2008), 62).

62 Tolley (2013), 122-24.

${ }^{63}$ Sellars (1956), reprinted in Sellars (1963); cf. McDowell (1996); McDowell (1998a), McDowell (1998b), McDowell (1998c); Abela (2002)

${ }^{64}$ Cf. Watkins (2008); Watkins (2012).

${ }^{65}$ Sellars (1956), reprinted in Sellars (1963), 128. All further page references will be to the reprint. Cf. BonJour (1985), ch. 4. 
lief. ${ }^{66}$ For example, John McDowell argues that

The idea of the Given is the idea that the space of reasons, the space of justifications' or warrants, extends more widely than the conceptual sphere. But we cannot really understand the relations in virtue of which a judgment is warranted except as relations within the space of concepts: relations such as implication or probabilification, which hold between potential exercises of conceptual capacities ${ }^{67}$

The passage in Kant typically adduced in support of this point is the "same function" passage at (A79/B104-5) quoted in $\S 4.3$ above. ${ }^{68}$ Thus, according to this conceptualist reading of Kant, sense experience would have the requisite proposition-like structure, and thus be capable of standing in justificatory relations to beliefs, since the same capacities that structure the contents of judgment for Kant (viz. the categories) would also structure sensory experience. While such interpreters are surely correct that Kant's aim, as exemplified in this passage, is to show that the very same cognitive capacities which connect representations in a mental act of judging are also in play in the connection of representations in a sensory experience, it is not obvious how the passage directly supports any argument concerning the epistemic significance of perceptual experience to knowledge. Endorsement of the premise principle is a substantive epistemological commitment, and despite what Kant says in the A79/B104-5 passage concerning the unity of judgment and intuition, it is not at all obvious that Kant endorses the principle. ${ }^{69}$ Hence further work needs to be done to show that Kant actually endorses or even articulates this argument.

A second objection against the Given, that might be attributed to Kant, is that the mere occurrence of a sensory experience cannot license any particular belief. Instead, sensory experience can only play its justificatory role against a background of concepts possessed by the experiencing subject. ${ }^{70}$ This connects to Kant at least in the sense that, if the conceptualist reading is correct, there is a particular battery of concepts

\footnotetext{
${ }^{66}$ See Pryor (2005); Siegel and Silins (Forthcoming); McLear (Forthcoming b), $§ 4.3$ for discussion.

${ }^{67}$ McDowell (1996), 7; cf. BonJour (1985),78; Davidson (1986), 310; Brewer (1999), 154

${ }^{68}$ See e.g. Sellars (1968), 4-5; McDowell (2003), 79; Haag (2007), 150-1, 199, and ch. 8; Kalderon (2011), 235-6. Cf. Pippin (1982), 99-101; Heidegger (1997), 45-6; Longuenesse (1998), 200; Grüne (2009), 107-11.

${ }^{69}$ For example, according to at least one prominent interpretation of Kant's epistemology, Kant endorses an at least partly "externalist" position concerning epistemic justification, and thus does not endorse the premise principle in the manner required to plausibly attribute to him this version of the "Myth of the Given" argument. See Chignell (2007b), 49-50; McLear (Forthcoming b), §4.3.

${ }^{70}$ Sellars (1963), 170; McDowell (1998a), 435-6.
} 
necessary for any perceptual experience to play a role in justification or the acquisition of empirical knowledge-viz. the categories. ${ }^{71}$

Again though, one might worry about attributing the above argument to Kant. Certainly Kant thought that empirical intuition alone was insufficient to count as empirical knowledge and that the legitimate application of the categories was necessary for any such knowledge. But much more would need to be said regarding whether or how intuition might stand in epistemic relations to beliefs. ${ }^{72}$ There is no straightforward route from Kant's argument concerning the role of the categories in empirical knowledge to the conclusion that the epistemological status of intuition depends on the categories. Indeed, there may be reasons to think that Kant would reject such a claim.

For example, Kant seems to hold that in intuition we "prove the possibility" of the subject matter of our thoughts. Kant makes this point explicitly in the preface to the B-edition of the first Critique.

To cognize an object, it is required that I be able to prove its possibility (whether by the testimony of experience from its actuality or a priori through reason). But I can think whatever I like, as long as I do not contradict myself, i.e., as long as my concept is a possible thought, even if I cannot give any assurance whether or not there is a corresponding object somewhere within the sum total of all possibilities. But in order to ascribe objective validity to such a concept (real possibility, for the first sort of possibility was merely logical) something more is required (Bxxvi).

Here Kant contrasts merely logically possible thought, in which one brings together logically compossible concepts, with the kind of real empirical possibility necessary for cognition. Kant distinguishes between these two sorts of possibility in terms of the notion of cancellation [Aufhebung]. The subject matter of a thought is logically possible if the thought's constituent concepts may be combined in judgement without contradiction, and thus without being logically cancelled out (A151/B190; NM 2:171-2). The subject matter of a thought is really possible, in contrast, if it can be shown that the subject matter to which the thought corresponds consists of properties which are mutually empirically compossible and not, in Kant's terms, "really repugnant." Kant often illustrates this idea with examples involving physical forces (e.g. opposite motions, opposing

${ }^{71}$ McDowell (1996); Ginsborg (2006b), Ginsborg (2008). It is not actually clear that only the conceptualist reading can accommodate this aspect of Kant's view. A non-conceptualist may well agree that the categories are necessary for empirical knowledge while nevertheless denying that they are necessary in accounting for the intentionality of perceptual experience. Cf. Hanna (2001), 46-65, Hanna (2005), 2567; Bird (2006), 193-207; Watkins (2008); Allais (2009), 392-4; Watkins (2012); Tolley (2013); McLear (Forthcoming a), §3; McLear (Forthcoming b), §5.2.

${ }^{72}$ For discussion see Stevenson (2003); Chignell (2007a), Chignell (2007b); Watkins (2008), Watkins (2012). 
attractive and repulsive forces; cf. A264-5/B320-1). Moreover, Kant considered a further kind of repugnance, wherein the subject itself is "cancelled out". In other words, it would be impossible for any being to exist that would instantiate such repugnant properties. ${ }^{73}$ In order for knowledge to be possible, the demonstration of the real possibility of the object of knowledge must be secured. If this is correct then there seems to be at least a prima facie tension between attributing to Kant both the claim that possession of some battery of concepts is necessary for intuition to have epistemic standing, and the claim that it is via intuition that one's concepts (or the judgments constituted by them) first attain epistemic legitimacy. How could a concept confer epistemic standing to intuition prior to that concept's being shown to be legitimate? They may well be a Kantian basis for answering this question, but more needs to be said by the conceptualist to defend the supposed Kantian provenance of this second version of the "Myth of the Given" argument. $^{74}$

Finally, both Sellars and McDowell claim that it is simply a mistake to think that mental states which are purely the upshot of causal interactions with the world could themselves stand as reasons for empirical belief. Sellars remarks that such a mistake is "of a piece with the so-called 'naturalistic fallacy' in ethics" (Sellars (1963), 146). Sellars himself gives no clear argument for this claim. ${ }^{75}$ McDowell focuses on the distinction between the kinds of mental states, the occurrence of which we are responsible for, such as judgment, and those which simply happen to us, in the way that, e.g. a fit of sneezing might happen to one. ${ }^{76}$ Once again, we can see the suggested parallel in a conceptualist reading of Kant. If conceptual capacities, such as the categories, are necessary for the occurrence of perceptual experience then experience is not merely something that causally happens to the subject, but rather is something that the subject herself partially accounts for, in much the same way that she accounts for her endorsement of the content of propositional judgment. It is not clear that this argument is construed as anything more than Kantian in spirit. Certainly though, there does seem to be a deeply Kantian point behind the notion that reasoning is thinking for oneself, and that this requires that the structure of one's thoughts be, in some sense, determined by oneself. ${ }^{77}$

\footnotetext{
${ }^{73}$ For discussion see Chignell (2011), 144-5; Chignell (2014); McLear (Forthcoming b), §§4.3 and 5.2.

${ }^{74} \mathrm{~A}$ further possibility is that Kant's views are genuinely divided here, and that subsequent moves in German idealism reflect this fact. See Pippin (1989), ch. 2 and the sources cited in note 57 above.

${ }^{75}$ Watkins (2008); Watkins (2012).

${ }^{76}$ McDowell (1996), ch. 1-2; McDowell (1998a), 433-4; McDowell (2003), 80-5; cf. Engstrom (2006), $8-13$.

77 This suggests that Kant's views of practical and theoretical reason have a broader unity. For one classic statement of such an interpretation see O'Neill (1989), ch. 1; cf. Stevenson (2004); McDowell (2009), chs. 4,5 , and 7 .
} 
$[\mathrm{O}]$ ne cannot possibly think of a reason that would consciously receive direction from any other quarter with respect to its judgments; since the subject would then attribute the determination of his judgment, not to his reason but to an impulse. Reason must regard itself as the author of its principles independently of alien influences. (G 4:448)

Whether or not Kant himself intended his arguments concerning the role of concepts in experience to be taken in the ways that Sellars, McDowell, and others have suggested, it is clear that he has been a central source of inspiration for these positions. Needless to say, the dispute as to Kant's exact position regarding these matters continues. ${ }^{78}$

\section{Summary}

To say that Kant is a conceptualist is, as we have seen, to say that he thinks (i) the content of an intuition (i.e. an "experience" in our contemporary sense) is a kind of representational relation to an object; (ii) such relation to an object depends on a synthesis directed in accordance with concepts; (iii) synthesis in accordance with concepts sets correctness conditions for the intuition's representation of a mind-independent object. The conceptualist reading promises to make sense of Kant's argument in the Transcendental Deduction by showing how perceptual experience depends on a synthesis by the categories. Assuming that we have such experience, if the categories are necessary for perceptual experience, then they have legitimate application to the objects of experience. In this manner conceptualism purports to have an interpretive advantage over non-conceptualist readings. Conceptualists further claim that their reading best explains how perceptual experience could play a justificatory role in the fixation of belief.

However, we have also seen several apparent problems for the conceptualist reading. First, though much of what the conceptualist says may be true of Kant's views concerning "Cognition" [Erkenntnis] (or "experience" [Erfahrung] as he often uses the term) it is less clear that it is true of perceptual experience or intuition. Second, the conceptualist must be able to account for the more primitive role that perception seems to play in Kant's cognitive theory, as well as the seeming fact that he acknowledges that perceptual experience is something we share with non-rational animals. Third, conceptualist readings seem to threaten the coherence of the arguments of the Transcendental Aesthetic, and thus the coherence of Kant's broader critical position. Fourth, Kant's own philosophy of mathematics may require that intuition be understood as a form of nonconceptual representation. Finally, it is not at all clear that, for Kant, intuitions have

${ }^{78}$ Hanna (2011a) disputes the idea that Kant is centrally concerned with denying the role of the Given in the way suggested by Sellars and McDowell. See also the references cited in note 71 above. 
correctness conditions. This is a basic assumption of the conceptualist position and is presupposed by its other commitments.

Going forward, conceptualism needs to clarify how its reading is compatible with Kant's arguments in the Transcendental Aesthetic, as well as his views regarding the cognitive capacities of non-rational animals. It also needs to do more to motivate confidence in the genuinely Kantian provenance of the family of arguments that go under the moniker of criticisms of the "Myth of the Given." Similarly, the non-conceptualist reading would be greatly helped by a more extensive account of the compatibility of non-conceptualism with the argument of the Transcendental Deduction. Both sides of the debate need also to account for objections to the content assumption. Much of the furor over Kant's endorsement or denial of conceptualism has tracked contemporary issues in the philosophy of perception. But whatever the fortunes of conceptualism and non-conceptualism as contemporary philosophical doctrines, our understanding of Kant's philosophy, and in particular his theory of cognition, has been greatly extended by the debate. ${ }^{79}$

\section{References}

Abela, Paul (2002). Kant's Empirical Realism. New York: Oxford University Press (p. 22). Adams, Robert Merrihew (1994). Leibniz: Determinist, Theist, Idealist. Oxford: Oxford University Press (p. 9).

Allais, Lucy (2009). "Kant, Non-Conceptual Content and the Representation of Space". In: Journal of the History of Philosophy 47.3, pp. 383-413. doi: 10.1353/ hph . $\odot$. 0134 (pp. 8, 13, 18-20, 22, 24).

Anderson, R. Lanier (2001). "Synthesis, Cognitive Normativity, and the Meaning of Kant's Question, 'How Are Synthetic Cognitions a Priori Possible?'" In: European Journal of Philosophy 9.3, pp. 275-305 (p. 15).

- (2004). "It Adds up after All: Kant's Philosophy of Arithmetic in Light of the Traditional Logic". In: Philosophy and Phenomenological Research 69.3, pp. 501-540 (p. 10).

- (2005). "The Wolffian Paradigm and Its Discontents: Kants Containment Definition of Analyticity in Historical Context". In: Archiv für Geschichte der Philosophie 87.7, pp. 22-74 (p. 10).

Aquila, Richard E. (1983). Representational Mind: A Study of Kant's Theory of Knowledge. en. Bloomington: Indiana University Press (p. 18).

- (2003). "Hans Vaihinger and Some Recent Intentionalist Readings of Kant". In: Journal of the History of Philosophy 41.2, pp. 231-250 (p. 18).

${ }^{79}$ Thanks to Derk Pereboom, Clinton Tolley, and the participants in my graduate seminar on conceptualism at the University of Nebraska-Lincoln in the fall of 2013 for helpful discussion and comments. 
Aquila, Richard E. (2008). "Intentional Objects and Kantian Appearances". In: Philosophical Topics 12.2, pp. 9-37 (p. 18).

Bird, Graham (2006). The Revolutionary Kant: A Commentary on the Critique of Pure Reason. Peru, IL: Open Court Publishing Company (pp. 19, 20, 24).

Bonjour, Laurence (1985). The Structure of Empirical Knowledge. en. Cambridge, MA: Harvard University Press (pp. 22, 23).

Brewer, Bill (1999). Perception and Reason. New York: Oxford University Press (p. 23). Brook, Andrew (2013). "Kant and Time-Order Idealism". en. In: A Companion to the Philosophy of Time. Ed. by Adrian Bardon and Heather Dyke. Oxford: Wiley-Blackwell, pp. 120-134 (p. 3).

Burge, Tyler (2003). "Perceptual Entitlement". In: Philosophy and Phenomenological Research 67.3, pp. 503-548 (pp. 11, 13).

Byrne, Alex (2009). "Experience and Content". In: The Philosophical Quarterly 59.236, pp. 429-451. doi: 10.1111/j.1467-9213.2009.614.x (p. 5).

Carson, Emily (1997). "Kant on Intuition and Geometry". In: Canadian Journal of Philosophy 27.4, pp. 489-512 (p. 10).

- (1999). "Kant on the Method of Mathematics". In: Journal of the History of Philosophy 37.4, pp. 629-652. doi: 10.1353/hph. 2008.0905 (p. 10).

Chignell, Andrew (2007a). "Belief in Kant". In: The Philosophical Review 116.3, pp. 323-360. doi: 10.1215/00318108-2007-001 (p. 24).

- (2007b). "Kant's Concepts of Justification". In: Noûs 41.1, pp. 33-63 (pp. 23, 24).

- (2011). "Real Repugnance and Our Ignorance of Things-in-Themselves: A Lockean Problem in Kant and Hegel". de. In: Internationales Jahrbuch des Deutschen Idealismus 2009: Glaube und Vernunft. Ed. by Fred Rush, Jürgen Stolzenberg, and Paul W. Franks. Berlin: Walter de Gruyter, pp. 135-159 (p. 25).

- (2014). "Kant and the 'Monstrous' Ground of Possibility". In: Kantian Review 19.1, pp. 53-69. doi: 10.1017/S1369415413000290 (p. 25).

Davidson, Donald (1986). "A Coherence Theory of Truth and Knowledge". In: Truth and Interpretation: Perspectives on the Philosophy of Donald Davidson. Ed. by Ernest LePore. Oxford: Basil Blackwell, pp. 307-319 (p. 23).

Engstrom, Stephen (2006). “Understanding and Sensibility”. In: Inquiry 49.1, pp. 2-25 (pp. 16, 25).

Evans, Gareth (1982). The Varieties of Reference. Ed. by John McDowell. Oxford: Oxford University Press (p. 11).

Falkenstein, Lorne (1995). Kant's Intuitionism: A Commentary on the Transcendental Aesthetic. en. Toronto: University of Toronto Press (p. 19).

Friedman, Michael (1992). Kant and the Exact Sciences. en. Cambridge: Harvard University Press (p. 10).

- (2012). "Kant on Geometry and Spatial Intuition". en. In: Synthese 186.1, pp. 231255. doi: 10.1007/s11229-012-0066-2 (pp. 9, 10). 
George, Rolf (1981). “Kant's Sensationism". In: Synthese 47.2, pp. 229-255. doi: 10 . $1007 /$ BF01064346 (p. 19).

Ginsborg, Hannah (2006a). "Empirical Concepts and the Content of Experience". In: European Journal of Philosophy 14.3, pp. 349-372 (pp. 8, 15).

- (2006b). "Kant and the Problem of Experience". In: Philosophical Topics 34.12, pp. 59-106. doi: 10.5840/philtopics2006341/24 (pp. 5, 8, 15, 24).

- (2008). "Was Kant a Nonconceptualist?" In: Philosophical Studies 137.1, pp. 6577. doi: 10.1007/s11098-007-9163-3 (pp. 8, 18, 20, 24).

Gomes, Anil (2010). "Is Kant's Transcendental Deduction of the Categories Fit for Purpose?" In: Kantian Review 15.02, pp. 118-137. doi: 10 . 1017 / S1369415400002466 (p. 21).

- (2014). "Kant on Perception: Naïve Realism, Non-Conceptualism and the BDeduction". In: The Philosophical Quarterly 64.254, pp. 1-19. doi: 10.1093/pq/ pqt019 (pp. 2, 8, 18, 21).

- (Manuscript). "In Kantian Phrase" (p. 18).

Griffith, Aaron M. (2012). "Perception and the Categories: A Conceptualist Reading of Kant's Critique of Pure Reason". en. In: European Journal of Philosophy 20.2, pp. 193-222. doi: 10.1111/j.1468-0378.2010.00404.x (pp. 2, 9, 16, 20, 21).

Grüne, Stefanie (2008). "Begriffe als Regeln der Wahrnehmung". In: Recht und Frieden in der Philosophie Kants: Akten des X Internationalen Kant-Kongresses. Ed. by Valerio Rohden et al. Berlin: Walter de Gruyter, pp. 267-278. doi: 10 . $1515 /$ 9783110210347.2 .267 (pp. 17, 18).

- (2009). Blinde Anschauung. Frankfurt am Main: Vittorio Klostermann (pp. 4-6, 17, 18, 23).

- (2011). "Is There a Gap in Kants B Deduction?" In: International Journal of Philosophical Studies 19.3, pp. 465-490 (p. 21).

Gunther, York H., ed. (2003). Essays on Nonconceptual Content. en. Cambridge: MIT Press (p. 1).

Haag, Johannes (2007). Erfahrung und Gegenstand. Frankfurt am Main: Vittorio Klostermann (p. 23).

Hanna, Robert (2001). Kant and the Foundations of Analytic Philosophy. Oxford: Oxford University Press (p. 24).

- (2002). "Mathematics for Humans: Kant's Philosophy of Arithmetic Revisited". In: European Journal of Philosophy 10.3, pp. 328-352. doi: 10 . $1111 / 1468-0378$. 00165 (p. 10).

- (2005). "Kant and Nonconceptual Content". In: European Journal of Philosophy 13.2, pp. 247-290. doi: 10.1111/ j.0966-8373 .2005 .00229 . x (pp. 8, 13, 14, 24).

- (2006). Kant, Science, and Human Nature. Oxford: Clarendon Press (p. 14). 
Hanna, Robert (2008). "Kantian Non-Conceptualism". In: Philosophical Studies 137.1, pp. 41-64. doi: 10.1007/s11098-007-9166- 0 (pp. 13, 14, 22).

- (2011a). "Beyond the Myth of the Myth: A Kantian Theory of Non-Conceptual Content". In: International Journal of Philosophical Studies 19.3, pp. 323-398 (pp. 8, 14, 26).

- (2011b). "Kant's Non-Conceptualism, Rogue Objects, and the Gap in the B Deduction". In: International Journal of Philosophical Studies 19.3, pp. 399-415. doi: 10.1080/09672559.2011.595188 (pp. 13, 14, 21).

Heck, Richard G. (2000). "Nonconceptual Content and the "Space of Reasons"". In: The Philosophical Review 109.4, pp. 483-523 (p. 13).

Hegel, G. W. F. (1977). Hegel: Faith and Knowledge: An English translation of G. W. F. Hegel's Glauben und Wissen. en. Ed. by Walter Cerf and Henry Silton Harris. Albany: SUNY Press (p. 21).

Heidegger, Martin (1997). Kant and the Problem of Metaphysics. en. Bloomington: Indiana University Press (p. 23).

Hinton, John Michael (1973). Experiences: An Inquiry Into Some Ambiguities. en. Oxford: Oxford University Press (p. 5).

Howell, Robert (1973). "Intuition, Synthesis, and Individuation in the Critique of Pure Reason". In: Noûs 7.3. ArticleType: research-article / Full publication date: Sep., 1973 / Copyright (C) 1973 Wiley, pp. 207-232. doi: 10.2307/2214348 (p. 14).

Janiak, Andrew (2012). "Kant's Views on Space and Time". In: The Stanford Encyclopedia of Philosophy. Ed. by Edward N. Zalta. Winter 2012 (p. 9).

Kalderon, Mark Eli (2011). "Before the Law". en. In: Philosophical Issues 21.1, pp. 219244. doi: 10.1111/j.1533-6077.2011.00202.x (p. 23).

Keller, Pierre (1998). Kant and the Demands of Self-Consciousness. en. Cambridge: Cambridge University Press (p. 21).

La Rocca, Claudio (2008a). "Der dunkle Verstand: Unbewusste Vorstellungen und Selbstbewusstsein bei Kant". In: Recht und Frieden in der Philosophie Kants. Akten des X. Internationalen Kant-Kongresses 2, pp. 447-458 (p. 5).

- (2008b). "Unbewußtes und Bewußtsein bei Kant". In: Kant-Lektionen: Zur Philosophie Kants und zu Aspekten ihrer Wirkungsgeschichte. Ed. by Manfred Kugelstadt. Würzburg: Königshausen Neumann, pp. 47-68 (p. 5).

Land, Thomas (2011). "Kantian Conceptualism". In: Rethinking Epistemology 1, pp. 197-239 (pp. 15, 18, 21).

Longuenesse, Béatrice (1998). Kant and the Capacity to Judge. Princeton: Princeton University Press (pp. 9, 10, 15, 18, 21, 23).

MacFarlane, John (2002). "Frege, Kant, and the Logic in Logicism". In: Philosophical Review 111.1, pp. 25-65. doi: 10.1215/00318108-111-1-25. eprint: http: //philreview.dukejournals.org/cgi/reprint/111/1/25.pdf (p. 10). 
Matherne, Samantha (Unpublished). "Images and Kant's Theory of Perception". Unpublished manuscript (pp. 2, 15).

McDowell, John (1996). Mind and World: With a New Introduction. Cambridge, MA: Harvard University Press (pp. 8, 11, 12, 19, 22-25).

- (1998a). "Lecture I: Sellars on Perceptual Experience". In: The Journal of Philosophy 95.9, pp. 431-450 (pp. 22, 23, 25).

- (1998b). "Lecture II: The Logical Form of an Intuition". In: The Journal of Philosophy 95.9, pp. 451-470 (p. 22).

- (1998c). "Lecture III: Intentionality as a Relation". In: The Journal of Philosophy 95.9, pp. 471-491 (p. 22).

- (2003). "Hegel and the Myth of the Given". In: Das Interesse des Denkens: Hegel aus heutiger Sicht. Ed. by Wolfgang Welsch and Klaus Vieweg. München: Wilhelm Fink Verlag, pp. 75-88 (pp. 21, 23, 25).

- (2007). "Hegel's Idealism as Radicalization of Kant". In: Internationales Jahrbuch des deutschen Idealismus=International Yearbook of German Idealism 5. Reprinted in McDowell 2009, 69-89, pp. 157-175 (p. 21).

- (2008). "Avoiding the Myth of the Given". In: John McDowell: Experience, Norm and Nature. Ed. by Jakob Lindgaard. Oxford: Blackwell, pp. 1-14 (p. 14).

- (2009). Having the World in View: Essays on Kant, Hegel, and Sellars. Cambridge: Harvard University Press (p. 25).

- (2013). "Perceptual Experience: Both Relational and Contentful". en. In: European Journal of Philosophy 21.1, pp. 144-157. doi: 10.1111/ ejop. 12005 (p. 14).

McLear, Colin (2011). "Kant on Animal Consciousness". In: Philosophers' Imprint 11.15, pp. 1-16 (pp. 5, 8, 19).

- (Forthcoming a). "Two Kinds of Unity in the Critique of Pure Reason". In: Journal of the History of Philosophy (pp. 8, 9, 17, 20-22, 24).

— (Forthcoming b). "Kant on Perceptual Content". In: Mind (pp. 2, 8, 13, 15, 16, $23-$ 25).

Messina, James (2014). "Kant on the Unity of Space and the Synthetic Unity of Apperception". In: Kant-Studien 105.1, pp. 5-40. doi: 10.1515/kant-2014-0002 (pp. 9, 21).

Naragon, Steve (1990). "Kant on Descartes and the Brutes". In: Kant-Studien 81.1, pp. 123 (pp. 8, 19).

O'Neill, Onora (1989). Constructions of Reason: Explorations of Kant's Practical Philosophy. en. Cambridge: Cambridge University Press (p. 25).

Onof, Christian and Dennis Schulting (Forthcoming). "Space as Form of Intuition and as Formal Intuition. On the Note to B160 in Kant's Critique of Pure Reason". In: The Philosophical Review (pp. 9, 21).

Parsons, Charles (1964). "Infinity and Kant's Conception of the "Possibility of Experience""'. In: The Philosophical Review 73.2. ArticleType: research-article / Full pub- 
lication date: Apr., 1964 / Copyright (C) 1964 Duke University Press, pp. 182-197. doi: $10.2307 / 2183335$ (p. 10).

Parsons, Charles (1992). "The Transcendental Aesthetic". In: The Cambridge Companion to Kant. Ed. by Paul Guyer. Cambridge: Cambridge University Press. Chap. 2, pp. 62-100 (p. 10).

Peacocke, Christopher (1992). A Study of Concepts. Cambridge, MA: MIT Press (p. 11). Pereboom, Derk (1988). "Kant on Intentionality". In: Synthese 77.3, pp. 321-352. doi: 10.1007/BF00869290 (pp. 18, 19).

Pereira, Roberto Horácio de Sá (2013). "What is nonconceptualism in Kant's philosophy?" en. In: Philosophical Studies 164.1, pp. 233-254. doi: 10. 1007 / s11098$011-9851-x$ (p. 14).

Pippin, Robert B. (1982). Kant's Theory of Form: An Essay on the Critique of Pure Reason. en. New Haven: Yale University Press (p. 23).

- (1989). Hegel's Idealism: The Satisfactions of Self-Consciousness. en. Cambridge: Cambridge University Press (pp. 21, 25).

Pryor, James (2005). "There is Immediate Justification". In: Contemporary Debates in Epistemology. Ed. by Matthias Steup and Ernest Sosa. Oxford: Blackwell. Chap. 7, pp. 181-202 (p. 23).

Rohs, Peter (2001). "Bezieht sich nach Kant die Anschauung unmittelbar auf Gegenstände?" In: Akten des 9. Internationalen Kant-Kongresses. Vol. II. Berlin: Walter De Gruyter, pp. 214-28 (p. 22).

Schulting, Dennis (2012). "Kant, Non-Conceptual Content and the 'Second Step' of the B-Deduction". In: Kant Studies Online, pp. 51-92 (pp. 15, 21).

Sellars, Wilfrid (1956). "Empiricism and the Philosophy of Mind". In: Minnesota studies in the philosophy of science 1, pp. 253-329 (p. 22).

- (1963). Science, Perception, and Reality. Atascadero, CA: Ridgeview Publishing Company (pp. 22, 23, 25).

- (1968). Science and Metaphysics: Variations on Kantian Themes. London: Routledge \& Keegan Paul (pp. 15, 23).

Shabel, Lisa (2006). "Kant's Philosophy of Mathematics". In: The Cambridge Companion to Kant and Modern Philosophy. Ed. by Paul Guyer. Cambridge: Cambridge University Press, pp. 94-128 (p. 10).

Siegel, Susanna (2010). "The Contents of Perception". In: The Stanford Encyclopedia of Philosophy. Ed. by Edward N. Zalta. Fall 2013 (p. 1).

Siegel, Susanna and Nicholas Silins (Forthcoming). "The Epistemology of Perception". In: Oxford Handbook of Philosophy of Perception. Ed. by Mohan Matthen. Oxford: Oxford University Press (p. 23).

Smit, Houston (2000). "Kant on Marks and the Immediacy of Intuition". In: The Philosophical Review 109.2, pp. 235-266 (p. 4). 
Speaks, Jeff (2005). "Is There a Problem about Nonconceptual Content?" In: The Philosophical Review 114.3, pp. 359-398 (p. 13).

Stevenson, Leslie (2003). “Opinion, Belief or Faith, and Knowledge". In: Kantian Review 7.1, pp. 72-101 (p. 24).

- (2004). "Freedom of Judgement in Descartes, Hume, Spinoza and Kant". In: British journal for the history of philosophy 12.2, pp. 223-246 (p. 25).

Strawson, Peter Frederick (1966). The Bounds of Sense. London: Routledge (p. 15).

- (1970). "Imagination and Perception". In: Experience and Theory. Ed. by Lawrence Foster and Joe William Swanson. Amherst: University of Massachusets Press (p. 15).

Sturm, Thomas and Falk Wunderlich (2010). "Kant and the Scientific Study of Consciousness". In: History of the human sciences 23.3, pp. 48-71. doi: 10 . 1177 / 0952695110363355 (p. 5).

Sutherland, Daniel (2008). "Arithmetic from Kant to Frege: Numbers, Pure Units, and the Limits of Conceptual Representation". In: Kant and Philosophy of Science Today. Ed. by Michela Massimi. Vol. 63. 1. Cambridge: Cambridge University Press, pp. 135-164. doi: 10.1017/S1358246108000088 (p. 10).

Thompson, Manley (1972). "Singular Terms and Intuitions in Kant's Epistemology". In: The Review of Metaphysics 26.2, pp. 314-343 (p. 16).

Tolley, Clinton (2011). "Kant on the Content of Cognition". In: European Journal of Philosophy, n/a-n/a. doi: 10.1111/j.1468-0378.2011.00483 x (pp. 13, 15).

- (2013). "The Non-Conceptuality of the Content of Intuitions: A New Approach". In: Kantian Review 18.01, pp. 107-136. doi: 10.1017/ 1369415412000313 (pp. 8, $13,15,16,20,22,24)$.

Van Cleve, James (1999). Problems from Kant. Oxford: Oxford University Press (pp. 3, $5,19)$.

- (2012). "Defining and Defending Nonconceptual Contents and States". In: Philosophical Perspectives 26.1, pp. 411-430 (p. 1).

Watkins, Eric (2008). "Kant and the Myth of the Given". In: Inquiry 51.5, pp. 512-531 (pp. 15, 22, 24, 25).

- (2012). "Kant, Sellars, and the Myth of the Given". en. In: The Philosophical Forum 43.3, pp. 311-326. doi: 10.1111/j .1467-9191.2012.00427 x (pp. 22, 24, 25).

Waxman, Wayne (1991). Kant's Model of the Mind: A New Interpretation of Transcendental Idealism. en. Oxford: Oxford University Press (p. 21).

Wenzel, Christian Helmut (2005). "Spielen nach Kant die Kategorien schon bei der Wahrnehmung eine Rolle? Peter Rohs und John McDowell". In: Kant-Studien 96.4, pp. 407-426 (p. 21).

Willaschek, Marcus (1997). "Der Transzendentale Idealismus und die Idealität von Raum und Zeit". In: Zeitschrift für philosophische Forschung 51.4, pp. 537-564 (pp. 16, 22).

July 21, 2014-Forthcoming in Philosophy Compass 
Williams, J. J. (2012). "How Conceptually Guided Are Kantian Intuitions?" In: History of Philosophy Quarterly 29.1, pp. 57-78 (p. 2).

Wunderlich, Falk (2005). Kant und die Bewußtseinstheorien des 18. Jahrhunderts. de. Berlin: Walter de Gruyter (pp. 5, 6). 